GPJI 4(2)(2020)

\title{
MOTIVASI SISWA PEREMPUAN DALAM MENGIKUTI PEMBELAJARAN PENDIDIKAN JASMANI SEKOLAH MENENGAH PERTAMA NEGERI (SMPN) SE-KOTA MALANG
}

Febrita Paulina Heynoek $^{1 \bowtie}$, Rama Kurniawan ${ }^{2}$, Fajar Raya Ferdinal Kusuma Bakti ${ }^{3}$

Afiliasi

e-mail korespondensi: febrita.paulina.fik@um.ac.id 1st $1^{\text {st }}$ rama.kurniawan.fik@um.ac.id 2nd, fajarrayafkb@gmail.com $3^{\text {rd }}$

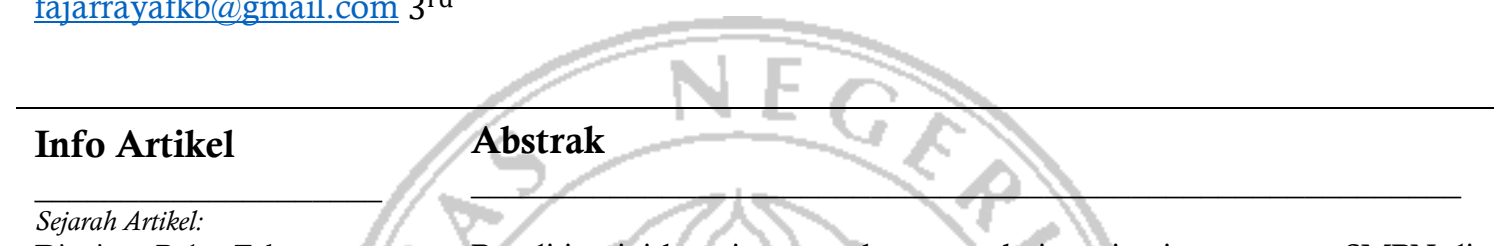

Diterima: Bulan-Tahun

Disetujui: Bulan-Tahun

Dipublikasikan : Bulan-Tahun

\section{Kata Kunci:}

Motivasi, perempuan, pendidikan jasmani.

Penelitian ini bertujuan untuk mengetahui motivasi perempuan SMPN di Kota Malang dalam mengikuti pembelajaran PJOK di sekolah. Penelitian ini menggunakan metode deskriptif kuantitatif dengan teknik survey. Sampel penelitian ini berjumlah 559 siswa Kelas VII,VIII dan IX menggunakan Cluster Random Sampling yang terbagi beberapa wilayah di Kota Malang. Instrumen tes yang digunakan yaitu kuesioner. Uji hipotesis untuk Uji Man Whitney dari empat kategori motivasi tersebut lebih kecil dari 0,05 ( $\mathrm{p}$ value $<0,05$ ), maka Ho ditolak artinya terdapat perbedaan yang signifikan pada kategori motivasi Intrinsic motivation, Identified regulation, Introjected regulation, External regulation antara siswa laki-laki dengan siswa perempuan. Sedangkan hasil Uji t' (aksen) dari kategori Amotivation tersebut lebih kecil dari 0,05 ( $\mathrm{p}$ value $<0,05$ ), maka Ho ditolak artinya terdapat perbedaan yang signifikan Amotivation antara siswa laki-laki dengan siswa perempuan. Dapat disimpulkan bahwa ada perbedaan yang signifikan dari motivasi siswa antara siswa laki-laki dan perempuan dalam mengikuti pembelajaran PJOK.

\section{Abstract}

This study aims to determine the motivation of women at SMPN in Malang City in participating in PJOK learning in schools. This research uses descriptive quantitative method with survey techniques. The research sample consisted of 559 students of Class VII, VIII and IX using cluster random sampling which was divided into several regions in Malang City. The test instrument used was a questionnaire. Hypothesis test for the Man Whitney Test of the four motivation categories is smaller than 0.05 ( $p$ value $<0.05$ ), so Ho is rejected, meaning that there is a significant difference in the motivation categories Intrinsic motivation, Identified regulation, Introjected regulation, External regulation among students. male with female students. While the results of the $t$ test (accent) of the Amotivation category were less than 0.05 ( $p$ value $<0.05$ ), so Ho was rejected, meaning that there was a significant difference in Amotivation between male students and female students. It can be concluded that there is a significant difference in student motivation between male and female students in participating in PJOK learning.

(C) 2019 Universitas Negeri Malang

\footnotetext{
Alamat korespondensi:
}

E-mail: pjk.journal@um.ac.id

ISSN: 2614-8293 (Online) 


\section{PENDAHULUAN}

Pendidikan jasmani merupakan salah satu mata pelajaran disekolah yang wajib diberikan kepada peserta didik yang terstruktur dalam program kurikulum. Pendidikan jasmani merupakan proses pembelajaran yang dilakukan melalui aktivitas gerak yang dibentuk untuk meningkatkan kebugaran jasmani, mengembangkan keterampilan motorik, perilaku hidup sehat dan pengetahuan, kecerdasan emosi dan sikap sportivitas.

Pendidikan jasmani wajib diterapkan dipembelajaran sekolah karena pendidikan jasmani mempunyai peranan penting dan strategis dalam rangka untuk membentuk karakter dan kelangsungan hidup peserta didik dilingkungan sekitar. Maka Pendidikan Jasmani bertujuan untuk memberikan manusia 1) tanggapan emosional, 2) hubungan pribadi, 3) mental intelektual, dan 4) keluaran estetika, dengan tetap tidak mengabaikan pengembangan kekuatan otot, tulang dan persendian, dengan tidak melupakan unsur keterampilan gerak, serta meningkatkan kebugaran jasmani manusia (Sudarsini, 2013). Untuk mencapai tujuan pendidikan jasmani diatas ini diperlukan suatu usaha pendidikan yang terbentuk dalam sistem dengan melibatkan beberapa faktor antara lain, guru, sarana dan prasarana serta motivasi siswa dalam mengikuti pembelajaran penjas disekolah.

Motivasi sudah digunakan lama sekali sejak awal abad kedua puluh. Sejak jaman dahulu manusia dikenal sebagai makhluk yang berfikir intelektual dan rasional. Motivasi jika didefinisikan merupakan segala sesuatu yang menjadi pendorong tingkah laku seseorang serta menuntut atau mendorong untuk memenuhi kebutuhan. Motivasi menjadi daya penggerak perilaku manusia sekaligus penentu perilaku. Motivasi juga bisa dikatakan sebagai suatu tindakan dalam mengenai terjadinya perilaku meliputi pengaturan, tujuan, dan pengarahan dari seseorang perilaku. Motivasi merupakan kekuatan penggerak yang bisa membangkitkan aktivitas pada makhluk hidup, dan dapat menimbulkan tingkah laku serta mengarahkannya menuju tujuan tertentu. Sedangkan Menurut Hoy dan Miskel di dalam buku Shaleh (2008:132), Motivasi adalah kekuatan-kekuatan yang kompleks, dorongan-dorongan, kebutuhan-kebutuhan, pernyataan-pernyataan, ketegangan (Tension States), atau mekanisme-mekanisme lainnya yang memulai dan menjaga kegiatan-kegiatan yang diinginkan ke arah pencapaian tujuan-tujuan personal.

Motivasi menjadi kunci utama dalam keberhasilan siswa bila dalam dirinya terdapat suatu kemauan yang dominan untuk mencapai suatu keberhasilan belajar dan tentu akan berpengaruh juga pada perilaku siswa yang sesuai dengan tujuan pendidikan, motivasi dapat digunakan juga untuk menjadi tolak ukur keberhasilan siswa dalam meraih prestasi dalam dunia pendidikan. Tingginya motivasi siswa ini terhadap satu mata pelajaran tentu akan lebih bisa dipahami oleh siswa tersebut serta dapat digunakannya di dalam kehidupannya sehari-hari dan mampu diingat-ingat dalam jangka waktu yang lebih panjang.

Motivasi perempuan dan laki-laki tingkatan Sekolah Menengah Pertama dalam mengikuti pembelajaran penjas sangat berbeda dengan memasuki usia remaja awal yaitu masa puber. Menurut Kartono (2006), setiap anak puber memiliki karakter yang berbeda-beda dan banyak bentuk, antara lain berupa; rasa cemas, gelisah, kecenderungan menentang orang tua dan kakak serta konflik-konflik batin. Banyak perubahan yang dialami oleh anak puber seperti perubahan fisik yang paling menonjol, seperti laki-laki tumbuh jakun menjadikan suaranya berat dan tumbuh rambut disekitar kemaluan sedangkan perempuan mengalami banyak sekali perubahan fisik seperti bertumbuhnya payudara dan melebarnya pinggul perempuan, tidak hanya aspek anatomi, perbedaan juga ditemukan pada aspek fisiologis, salah satu aspek yang membedakan adalah menstruasi, ini yang membuat perempuan merasa mudah lelah serta memiliki suasana hati yang berubah-ubah dan perasaan yang sangat sensitif. Menstruasi merupakan keluarnya cairan darah yang berasal dari lapisan selaput lendir rahim yang 
dikeluarkan melalui kelamin wanita. Terjadinya menstruasi bisa menyebabkan seorang wanita merasa kram, mual, sakit kepala, nyeri pinggang, pegal-pegal dan emosional meningkat.

Perbedaan karakteristik antara perempuan dan laki-laki jelas nampak pada aspek anatomi tubuhnya. Hal ini sesuai dengan penelitian yang dilakukan oleh Budayati (2010) yang menyatakan bahwa olahraga dan aktivitas fisik lainnya akan mempengaruhi fisiologis reproduksi wanita salah satunya yaitu menstruasi. Apabila seseorang mengalami menstruasi maka tidak dianjurkan untuk melakukan aktivitas fisik yang berat. Tidak hanya itu, pada aspek anatomi tubuh wanita memiliki serabut otot yang lebih kecil dibandingkan pria, hal tersebut yang menjadi perbedaan kinerja antara wanita dan pria. Wanita cenderung lebih lemah dan lebih cepat lelah daripada pria, sehingga keduanya tidak bisa disamakan pada saat berolahraga (aktivitas fisik). Oleh karena aspek anatomi fisiologis wanita dan pria berbeda tentunya olahraga pada keduanya juga berbeda, baik dari segi intensitas maupun beban latihannya. Olahraga pada wanita harus memperhatikan kondisi tubuh dan sesuai dengan porsi latihannya, demikian juga pada penelitian ini. Oleh karena itu tingkat olahraga pada wanita harus diperhatikan, karena olahraga akan mempengaruhi aspek fisiologis wanita. Banyak hal yang dapat mempengaruhi motivasi siswa dalam mengikuti pendidikan jasmani yaitu: 1) Berat badan; 2) Penampilan; 3) Usia; 4) Kesegaran jasmani; dan 5) Kesehatan Jasmani.

Kota Malang dikenal baik karena dicap dengan sebutan Kota Pendidikan karena jumlah perguruan tinggi yang banyak dan sekolah-sekolahan yang mencapai puluhan sekolah, dari aspek lembaga pendidikan terutama Sekolah Menengah Pertama Negeri (SMPN) tercatat terdapat 27 SMP Negeri di Kota Malang ini, dengan banyaknya sekolah ini, setiap sekolahan mempunyai karakteristik dan beragam bentuk motivasi siswanya terutama siswa perempuan yang dikenal lemah lembut untuk mengikuti kegiatan olahraga, akan berbagai versi dan model motivasi mereka dalam mengikuti pembelajaran olahraga. Oleh karena itu alasan peneliti melakukan penelitian ini adalah belum adanya data penelitian tentang survey motivasi perempuan dalam mengikuti pembelajaran penjas, dengan mengacu pada beberapa indikator motivasi yang terdiri dari Intrinsic Motivation, Identified Regulation, Introjected Regulation, Eksternal Regulation, dan Amotivation, peneliti hanya ingin mengetahui motivasi siswa perempuan kelas VII, VIII dan IX dalam mengikuti pembelajaran Pendidikan Jasmani di Kota-Malang. Terdapat sekitar 27 Sekolah Menengah Pertama Negeri (SMPN) se-Kota Malang, dari semua sekolah itu berbeda-bedalah karakteristik siswanya tidak hanya itu beragamnya guru pengajar dalam membelajarkan siswa dan sarana prasarana yang disediakan oleh pihak sekolahan juga dapat mempengaruhi motivasi siswa. Jadi dalam pentingnya pembelajaran pendidikan jasmani bagi siswa perempuan Sekolah Menengah Pertama di Kota Malang serta belum adanya data dalam penelitian ini di SMP Negeri se-Kota Malang maka penelitian ini dilakukan untuk mengetahui bagaimana motivasi siswa perempuan dalam mengikuti pembelajaran Pendidikan Jasmani, Olahraga dan Kesehatan di sekolah oleh karena itu penelitian ini diperlukan untuk mengetahui. Motivasi Siswa Perempuan dalam Mengikuti Pembelajaran Pendidikan Jasmani Sekolah Menengah Pertama Negeri (SMPN) Se-Kota Malang.

\section{METODE}

Dalam memecahkan penelitian diatas maka dalam penelitian ini menggunakan desain penelitian deskriptif kuantitatif. Menurut Yusuf (2016) penelitian deskriptif kuantitatif memberikan informasi gambaran keadaan masa sekarang dengan mendalam serta mendeskripsikan secara sistematis, faktual, dan akurat sekaligus fakta dan menggambarkan fenomena secara detail.

Populasi penelitian ini adalah siswa Perempuan SMP Negeri Kelas VII, VIII dan IX di Kota Malang. Dalam penelitian ini pemilihan sampel menggunakan Cluster Random Sampling. Populasi yang digunakan dalam penelitian ini adalah siswa perempuan SMP Negeri se-Kota Malang dengan jumlah total 10.782 siswa perempuan dengan total 27 SMP Negeri. Besarnya sampel dalam penelitian ini ditentukan minimal 385 siswa perempuan yang dihitung menggunakan rumus Slovin, 
pengambilan sampel dalam penelitian ini menggunakan teknik sampling acak sistematis (Simple Random Sampling). Untuk mendapatkan data yang baik peneliti menyebarkan kuesioner dengan mendapatkan responden sebesar 595 siswa perempuan.

Instrumen yang digunakan dalam penelitian ini berupa non tes yaitu kuesioner angket motivasi dalam pembelajaran penjas. Pengumpulan data dalam penelitian ini berupa kuisioner angket motivasi, dengan cara mengajukan pertanyaan atau pernyataan tertulis dalam bentuk lembar kertas yang dibagikan atau non-tulis yaitu online berbentuk google form. Analisis data peneliti menggunakan metode analisis deskriptif presentase, alasan peneliti menggunakan metode persentase adalah peneliti tidak memiliki hipotesis. Hipotesis hanya digunakan jika yang dipermasalahkan menunjukkan antara dua variabel atau lebih.

\section{HASIL}

Dari 595 responden dapat dilihat tabel 1 hasil jawaban responden yang terdiri dari lima indikator, terlihat motivasi perempuan dalam lima indikator dibawah ini:

Tabel 1. Data Kategori Intrinsik Motivation

\begin{tabular}{lcccc}
\hline & N & Mean & Median & $\%$ \\
\hline Intrinsik Motivation & 595 & 20,99 & 20,00 & $25 \%$ \\
\hline
\end{tabular}

Adapun faktor Intrinsik Motivation yang mempengahuri motivasi siswa perempuan SMP Negeri se-Kota Malang dalam mengikuti pembelajaran penjas, diukur dengan 20 item pertanyaan, terdiri dari 7 skala jawaban jadi, untuk skor keseluruhan adalah 140. Dan jumlah responden 595 siswa. Berdasarkan analisis deskriptif, rata-rata faktor Intrinsik Motivation siswa perempuan dalam mengikuti pembelajaran penjas sebesar 20,99 dengan tingkat persentse sebesar 25\%.

\begin{tabular}{|c|c|c|c|c|}
\hline & $\mathbf{N}$ & Mean & Median & $\%$ \\
\hline $\begin{array}{l}\text { Identified } \\
\text { Regualtion }\end{array}$ & 5 & & & $24,2 \%$ \\
\hline
\end{tabular}

Faktor Identified Regulation yang mempengahuri motivasi siswa perempuan SMP Negeri seKota Malang dalam mengikuti pembelajaran penjas, diukur dengan 20 item pertanyaan, terdiri dari 7 skala jawaban jadi, untuk skor keseluruhan adalah 140. Dan jumlah responden 595 siswa. Berdasarkan analisis deskriptif, rata-rata faktor Intrinsik Motivation siswa perempuan dalam mengikuti pembelajaran penjas sebesar 20,33 dengan tingkat persentse sebesar 24,2\%.

Tabel 3. Data Kategori Introjected Regulation

\begin{tabular}{lcccc}
\hline & N & Mean & Median & $\%$ \\
\hline $\begin{array}{l}\text { Introjected } \\
\text { Regulation }\end{array}$ & 595 & 15,74 & 16,00 & $18,6 \%$ \\
\hline
\end{tabular}

Adapun faktor Introjected Regulation yang mempengahuri motivasi siswa perempuan SMP Negeri se-Kota Malang dalam mengikuti pembelajaran penjas, diukur dengan 20 item pertanyaan, terdiri dari 7 skala jawaban jadi, untuk skor keseluruhan adalah 140. Dan jumlah responden 595 siswa. Berdasarkan analisis deskriptif, rata-rata faktor Intrinsik Motivation siswa perempuan dalam mengikuti pembelajaran penjas sebesar 15,74 dengan tingkat persentse sebesar 18,6\%.

Tabel 4. Data Kategori External Regulation

\begin{tabular}{ccccc}
\hline & N & Mean & Median & $\%$ \\
\hline $\begin{array}{c}\text { External } \\
\text { Regulation }\end{array}$ & 595 & 16,23 & 16,00 & $19,3 \%$ \\
\hline
\end{tabular}


Faktor External Regulation yang mempengahuri motivasi siswa perempuan SMP Negeri seKota Malang dalam mengikuti pembelajaran penjas, diukur dengan 20 item pertanyaan, terdiri dari 7 skala jawaban jadi, untuk skor keseluruhan adalah 140. Dan jumlah responden 595 siswa. Berdasarkan analisis deskriptif, rata-rata faktor Intrinsik Motivation siswa perempuan dalam mengikuti pembelajaran penjas sebesar 16,23 dengan tingkat persentse sebesar 19,3\%.

Tabel 5. Data Kategori Amotivation

\begin{tabular}{lcccc}
\hline & $\mathbf{N}$ & Mean & Median & $\%$ \\
\hline Intrinsik Motivation & 595 & 10,89 & 11,00 & $13 \%$ \\
\hline
\end{tabular}

Adapun faktor Amotivation yang mempengahuri motivasi siswa perempuan SMP Negeri seKota Malang dalam mengikuti pembelajaran penjas, diukur dengan 20 item pertanyaan, terdiri dari 7 skala jawaban jadi, untuk skor keseluruhan adalah 140. Dan jumlah responden 595 siswa. Berdasarkan analisis deskriptif, rata-rata faktor Intrinsik Motivation siswa perempuan dalam mengikuti pembelajaran penjas sebesar 10,89 dengan tingkat persentse sebesar 13\%.

\section{PEMBAHASAN}

Berdasarkan hasil temuan penelitian yang telah dilakukan dengan jumlah sampel sebesar 595 siswa diketahui bahwa motivasi mereka dengan lima indikator selisihnya sedikit berbeda-beda dari dari jawaban semua responden siswa SMP Negeri se-Kota Malang. Menurut Sogunro (2014) Motivasi merupakan "The reality is that in all teaching and learning transaction, motivation is an inevitable contruct that evokes and sustains effective learning", yang berarti bahwa semua dalam transaksi belajar dan mengajar harus adanya motivasi karena dengan adanya motivasi bisa mempengaruhi efektifitas dalam pembelajaran.

Menurut Sansone dan Harackiewicz (2000) Intrinsic motivation ini terkandung dalam diri seseorang setiap akan berperilaku untuk kepuasan yang sudah melekat dalam perilaku itu sendiri. Menurut Haerens, dkk (2019) Dengan menyuarakan keinginan siswa dalam keprihatinan, dan masalah siswa mungkin siswa akan merasa dihargai dan oleh karena itu siswa lebih berkehendak di dalam pembelajaran mereka. Pendapat di atas seharusnya bisa diterapkan oleh guru mata pelajaran PJOK segala sesuatu yang diajarkan oleh guru sedapat mungkin bisa menarik siswa secara intrinsik khususnya siswa perempuan, karena siswa perempuan yang sulit untuk mengikuti kegiatan ini. Untuk meningkatkan motivasi intrinsik siswa perempuan, pendidik dapat memberikan siswanya dengan lingkungan yang mendukung otonomi dan mungkin secara positif mempengaruhi tingkat aktivitas di kelas (Ward dkk., 2008).

Siswa yang termotivasi karena indikator Identified regulation juga masih banyak dari data diatas ini membuktikan masih tingginya rasa siswa ingin mereka ketahui, faktornya bisa saja mereka ingin tahu secara langsung informasi tersebut atau jika melakukan hal tersebut mereka akan mendapatkan manfaat untuk mereka sendiri, Identified regulation dianggap sebagai pilihan diri, dipilih secara bebas dan konsisten dengan nilai-nilai dan kepercayaan individu (C. Sansone \& Harackiewicz, 2012).

Indikator Introjected Regulation siswa laki-laki dan perempuan persentasenya lebih tinggi siswa laki-laki. Hal ini menunjukkan bahwa siswa laki-laki terdapat dorongan dari diri sendiri dalam melakukan pembelajaran pendidikan jasmani olahraga dan kesehatan. Tetapi, mereka melakukannya dengan terpaksa atau ada perasaan takut jika tidak melakukan hal tersebut. Siswa yang termotvasi ini tidak atas kehendaknya sendiri jadi ada paksaan dari batinnya bukan dari orang lain, dikarenakan ada rasa kewajiban dalam melakukan (Kalajas, dkk 2019).

Pada External regulation, siswa perempuan memiliki kecenderungan yang tinggi dibandingkan laki-laki. Hal ini disebabkan siswa perempuan masih banyak dalam mengikuti pembelajaran PJOK, mereka ingin mendapatkan hadiah atau reward dari guru, bisanya untuk perempuan dalam mengikuti pembelajaran PJOK sangatlah rendah atau malas mengikuti jadi untuk 
itu bagaimana upaya guru menyikapi hal tersebut dengan memberinya pujian, nilai, hadiah, dan masih banyak lagi yang tujuan dari motivasi ini adalah agar siswa mau melakukan atau mampu mengikuti pembelajaran.

Sedangkan untuk indikator Amotivation perempuan lebih tinggi selisih $0,2 \%$ dari laki-laki, ini menunjukkan perempuan kurang termotivasi dalam mengikuti pembelajaran dari data yang diperoleh terdapat 77 siswa perempuan yang tidak termotivasi dalam mengikuti pembelajaran PJOK. Banyak faktor yang mempengaruhi siswa tidak termotivasi ini kuat adanya banyak SMP Negeri di Kota Malang ini melaksanakan program Full Day School, jadi siswa yang seharusnya belajar muai pukul 07.00-13.00 WIB karena ada Full Day School siswa belajar hingga pukul 15.15 WIB. Menurut Heynoek dkk (2018) kemampuan motorik siswa SMP yang menerapkan Full Day School sangatlah kurang. Dari tanggapan di atas menjukkan siswa dan siswi SMP untuk motivasi melakukan pembelajaran PJOK sangatlah rendah karena faktor Full Day School yang memaksa mereka untuk belajar terus menerus, jika dibandingkan siswa melakukan jam olahraga pada pagi hari awal pelajaran dan siang hari diakhir jam pelajaran maka motivasi mereka untuk antusias melakukan olahraga juga berbeda-beda.

Keberadaan gender sangat mempengaruhi perilaku, mental, sikap dan karakterisrik individu. Perbedaan antara perempuan dan laki-laki jelas nyata dan nampak dalam aspek anatomi, tetapi dalam sisi fisiologis perbedaannya kurang jelas (Gregg \& Gregg, 2017). Sehingga faktor tersebut dapat mempengaruhi perbedaan motivasi siswa laki-laki dan perempuan dalam mengikuti pembelajaran PJOK. Dalam penelitian Marbun (2018) siswa perempuan akan lebih rajin daripada siswa laki-laki. Sedangkan menurut Kurniyawan (2016) ada perbedaan perkembangan antara siswa laki-laki dan perempuan, secara umum laki-laki memiliki gerak reflek yang sangat baik dibandingkan perempuan, koordinasi anggota tubuh laki-laki dirancang untuk bisa bekerja sama menerima respon dari luar secara cepat, dan perempuan memiliki kecemasan atau rasa gugup yang lebih tinggi, perasaan inilah yang mempengaruhi motivasi siswa siswa perempuan. Menurut Shihab (2004) jumlah kadar darah merah pada perempuan lebih sedikit ketimbang pria, kemampuannya bernapas juga lebih rendah daripada laki-laki dan untuk ototnya tidak sekekar otot laki-laki. Menurut Griwijoyo (2007) Diameter dan masa otot wanita dapat ditingkatkan dengan latihan yang sistematis, tetapi bagaimana pun tidak dapat menyamai kaum laki-laki dikarenakan kadar testoteronnya lebih rendah dari kaum laki-laki.

Peran guru sangat lah penting dalam membangun sistem pembalajaran dikelas. Awalnya, para guru mungkin merasa perlu untuk mengendalikan dan memeberikan tekanan kepada siswa sehingga mereka akan dapat berupaya melakukan tugas motorik, tetapi mereka perlu menyadari bahwa ini seringkali dapat merusak persepsi dan aktivitas fisik mereka dalam mengikuti pembelajaran. Guru tidak harus fokus secara eksklusif pada keterampilan teknis, strategis, dan taktis siswa, tetapi juga harus fokus pada upaya pengembangan hubungan yang efektif dengan siswa, sehingga dalam kelas pendidikan siswa mengalami emosi yang positif selama pembelajaran (Trigueros dkk., 2019). Jadi dengan data diatas dapat dinyatakan bila siswa SMP Negeri se-Kota Malang tingginya Intrinsic Motivation dan Identified Regulation ini menunjukkan kalau banyak siswa yang terdorongan motivasi mereka dari dalam dirinya sendiri dalam mengikuti pembelajaran Pendidikan Jasmani Olahraga dan Kesehatan (PJOK).

\section{KESIMPULAN}

Sejalan dengan hasil data pembahasan maka dapat disimpulkan. Bahwa, ada perbedaan yang signifikan dari motivasi siswa antara siswa laki-laki dan perempuan dalam mengikuti pembelajaran Pendidikan Jasmani Olahraga dan Kesehatan di SMP Negeri se-Kota Malang. 


\section{DAFTAR PUSTAKA}

Gregg, E. A., \& Gregg, V. H. (2017). Women in Sport. Clinics in Sports Medicine, 36(4), 603-610. https://doi.org/10.1016/j.csm.2017.05.001

Griwijoyo, S. (2007). Wanita dan Olahraga. FPOK UPI.

Haerens, L., Krijgsman, C., Mouratidis, A., Borghouts, L., Cardon, G., \& Aelterman, N. (2019). How does knowledge about the criteria for an upcoming test relate to adolescents' situational motivation in physical education? A self-determination theory approach. European Physical Education Review, 25(4), 983-1001.

Heynoek, F. P., Amiq, F., \& Rahman, G. (2018). SURVEI TENTANG KEMAMPUAN MOTORIK SISWA-SISWI SEKOLAH MENENGAH PERTAMA FULL DAY SCHOOLDANREGULERDI KOTA MALANG. SKRIPSI Jurusan Pendidikan Jasmani dan Kesehatan - Fakultas Ilmu Keolahragaan UM, 0(0). http://karyailmiah.um.ac.id/index.php/Penjaskes/article/view/75402

Kalajas-Tilga, H., Koka, A., Hein, V., Tilga, H., \& Raudsepp, L. (2019). Motivational processes in physical education and objectively measured physical activity among adolescents. Journal of Sport and Health Science, 00 (2019) 1-10. https://doi.org/10.1016/j.jshs.2019.06.001

Kartono, K. (2006). Psikologi Wanita 1/ Mengenal Gadis Remaja dan Wanita Dewasa. MANDARMAJU.

Kurniyawan, O. (2016). PERBEDAAN PERTUMBUHAN FISIK DAN PERKEMBANGAN MOTORIK KASAR SISWA LAKI-LAKI DAN PEREMPUAN KELAS ATAS SDN KALONGAN 4 UNGARAN TIMUR. Universitas Negeri Semarang.

Marbun, S. (2018). Psikologi Pendidikan. Uwais Inspirasi Indonesia.

Sansone, C., \& Harackiewicz, J. (2012). Intrinsic and Extrinsic Motivation: The Search for Optimal Motivation and Performance.

Sansone, D. C., Sansone, C., \& Harackiewicz, J. M. (2000). Intrinsic and Extrinsic Motivation: The Search for Optimal Motivation and Performance. Academic Press.

Shaleh, A. R., \& Wahab, M. A. (2008). Psikologi: Suatu pengantar dalam Perspektif Islam (1 ed.). KENCANA.

Shihab, M. Q. (2004). Jilbab, Pakaian Wanita Muslimah: Pandangan Ulama Masa Lalu dan Cendikiawan Kontemporer. Penerbit Hentera Hati. https://books.google.co.id/books?hl=en\&lr=\&id=XJHvCAAAQBAJ\&oi=fnd\&pg=PR1\&dq $=$ pubertas+wanita\&ots $=\mathrm{MbCxArEN2d \& sig=IS2kettjnIvGiYSxZFZyDuPiudQ \& redir \_ esc=y}$ $\# \mathrm{v}=$ onepage $\& \mathrm{q}=$ pubertas $\% 20$ wanita\& $\mathrm{f}=$ false

Sogunro, O. A. (2014). Motivating Factors for Adult Learners in Higher Education. International Journal of Higher Education, 4(1), 22. https://doi.org/10.5430/ijhe.v4n1p22

Sudarsini. (2013). Pendidikan Jasmani dan Olahraga. Fakultas Ilmu Pendidikan Universitas Negeri Malang.

Trigueros, R., Aguilar-Parra, J. M., Cangas, A. J., López-Liria, R., \& Álvarez, J. F. (2019). Influence of physical education teachers on motivation, embarrassment and the intention of being physically active during adolescence. International journal of environmental research and public health, 16(13), 2295.

Ward, J., Wilkinson, C., Graser, S. V., \& Prusak, K. A. (2008). Effects of Choice on Student Motivation and Physical Activity Behavior in Physical Education. Journal of Teaching in Physical Education, 27(3), 385-398. https://doi.org/10.1123/jtpe.27.3.385

Yusuf, M. (2016). Metode Penelitian Kuantitatif, Kualitatif \& Penelitian Gabungan. Prenada Media. 